\title{
Clearcuts and related secondary dieback undermine the ecological effectiveness of FSC certification in a boreal forest
}

Jeanette Silvin Blumröder ${ }^{1 *}$, Monika T. Hoffmann', Olga llina ${ }^{2,3}$, Susanne Winter ${ }^{4}$, Peter R. Hobson ${ }^{5}$ and Pierre L. Ibisch ${ }^{1}$

\begin{abstract}
Background: Over the last 25 years, the prominent forest certification system established by the Forest Stewardship Council (FSC) has used by many companies worldwide for claiming responsible forest management. The objectives of the Russian National FSC standard to decrease the size of clearcuts and the retention of forest elements such as residual seed trees need on-site validation to proof the effectiveness of FSC. To assess the ecological impacts of harvesting practices and benefits of FSC certification, we geospatially compared logging activities with and without FSC certification. Within a sample area covering approximately $3,000 \mathrm{~km}^{2}$ in the east of the Russian Arkhangelsk Region, we used available data on tree cover loss and satellite images to assess secondary impacts of clearcuttings on adjacent remnant forests and to quantify the logging intensity. Additionally, the size and structure as well as the density of skidding trails of ten specific clearcuttings located within the sample area were surveyed using satellite images and in the field observation to delineate the boundaries of clearcuts and forested remnants within the clearcuts.

Results: We found a significant increase of small-scale tree cover loss in the proximity of the clearcuts. Patchy dieback is possibly linked to the scale and intensity of logging in the surroundings. On the investigated clearcuts, FSC failed to reduce the size, to increase the retention of forest remnants including seed trees on logged areas, and to maintain larger tracts of undisturbed ground and soil compared to clearcuts that were logged before they received FSC-certification.
\end{abstract}

Conclusions: Trees and forest remnants remaining inside an increasingly stressed forest ecosystem matrix may not resist further harvesting-related and climate change-induced stresses and disturbances. Large-scale clearcuttings seem to have negative impacts even in adjacent forests and undermine the ecological effectiveness of FSC certification in the study area. The Russian FSC standard is not clearly setting effective guidelines that induce a change in clearcutting practices in order to reduce ecological risks.

Keywords: Ecological effectiveness, Impact assessment, Forest certification, Sustainable forestry

\section{Background}

Commercial timber extraction has profound impacts on forest ecosystems by causing a deterioration in structure and function, which inevitably affect the provision of other ecosystem services (Thompson et al. 2011; Miura et al. 2015). Biodiversity and especially the number of

\footnotetext{
* Correspondence: j.blumroeder@hnee.de

${ }^{1}$ Centre for Econics and Ecosystem Management, Eberswalde University for Sustainable Development, Alfred-Moeller-Str. 1, 16225 Eberswalde, Germany Full list of author information is available at the end of the article
}

forest-dependent species decline as intact forests are lost (Hanski and Haila 1988; Hanski and Ovaskainen 2000; Schmiegelow and Mönkkönen 2002). Forest fragmentation, habitat loss, and deteriorated forest functionality change soil nutrient status and its ability to support plant growth and food supply for animals along the food chain (Bradshaw et al. 2009). Currently, intact boreal forest landscapes cover about one third of the world's remaining forests and are characterized by vast areas with least human-induced disturbances and immense 
carbon sequestration (Bradshaw et al. 2009; Gauthier et al. 2015). The Russian Federation holds a large part of intact forest landscapes on its territory but at the same time suffers from rapid loss of such valuable forests due to economic activities as well as anthropogenic forest fires (Potapov et al. 2008, 2017). Efforts towards proactively preventing the loss of and prioritizing the conservation and restoration of intact forests are of global concern for biodiversity, climate, and sustainable development (Watson et al. 2014).

Forest certification systems were developed since the 1990s to safeguard biodiversity and ecosystem functions and have operated as market-based and voluntary schemes to promote and label more sustainable forest exploitation and at the same time tried to reconcile economic interests and social responsibility (Rametsteiner and Simula 2003; Auld et al. 2008). Over the last 25 years, the Forest Stewardship Council (FSC) established internationally a prominent certification system used by many companies in the timber business for claiming timber and woody products as responsibly produced. The FSC has gained global recognition and was approved as a measure for accomplishing at least 11 goals and 35 targets within the framework of the Sustainable Development Goals (SDG) (FSC 2016a; Ugarte et al. 2017). Despite considerable public, political, and scientific interest to understand and evaluate the effective impact of FSC around the globe, there are only few findings to show the benefits it provides for forest ecosystems (Blackman and Rivera 2010; Marx and Cuypers 2010; Blackman et al. 2015; Burivalova et al. 2017). The effectiveness of forest certification can be defined as the success of changing and mitigating negative environmental and socio-economic impacts caused by forestry (Gulbrandsen 2005).

Almost 200 million ha of the world's forest distributed across 83 countries are FSC-certified, and the Russian Federation boasts greatest coverage with more than 45 million hectares (FSC 2019). In the north west of the Russian Federation, in the Arkhangelsk Region, extensive areas of boreal forest are under certification that goes back many years encompassing almost all big companies (Lukashevich et al. 2016). The extent of forest brought under FSC certification has steadily increased since the scheme was first introduced to the region in 2004 (Blumroeder et al. 2018). Typically, forest in the Arkhangelsk Region is harvested under a clearcut regime and involves clearcuts of up to 50 ha in production forests (McDermott et al. 2010). Large areas of forest clear-felled in adjacent squares give rise to large "chequerboard patterns" clearly visible in satellite images (Blumroeder et al. 2018; Potapov et al. 2017; Potapov et al. 2009; Naumov and Angelstam 2014). The practice of clearcutting is endorsed by Russian forest legislation, and it can include primary forest. In the
Arkhangelsk Region, private enterprises conduct clearcuttings in pristine boreal forest ecosystems (Achard et al. 2006). Forest cover in Russia has changed rapidly and extensively over the last decades as a consequence of commercial timber extraction especially in European Russia (Achard et al. 2006), and future projections are for further tree cover loss (Hewson et al. 2019).

Clearcuttings are typically conducted using modern harvesters and skidding machinery to cut and extract timber. Mechanical disturbance due to tree harvesting operations alters the physical structure and chemical composition of forest soils to the extent that it can take more than 100 years to recover (Dymov 2017). Heavy machinery impacts the soil morphology and causes soil compaction and loss of porosity; under these conditions, aeration, water absorption, and retention are diminished, which can reduce forest function and productivity (Startsev and $\mathrm{McNabb}$ 2009; Cambi et al. 2015). Increased water runoff can contribute to soil erosion while exposed soils show higher temperature and are more likely to emit carbon (Tan et al. 2005). Forestry, and clearcutting in particular, reduces microbial and fungal biomass in soil (Tan et al. 2008; Holden and Treseder 2013). The root system and growth of plants is disrupted by soil compaction with associated changes in ion uptake (Nawaz et al. 2012).

The Russian National FSC Standard advises reducing the size of clearcuts to maintain ecosystem functioning, but clear and binding thresholds are not given in the set of Principles, Criteria, and Indicators (Blumroeder et al. 2018). Tree cover loss is a suitable indicator for quantifying timber harvesting activities, but was shown not to be influenced by FSC in the Russian Far East (Nikolaeva et al. 2019). Almost 1 million hectare of the Arkhangelsk Region was affected by tree cover loss by 2014, of which more than half was recorded within concessions that had been FSC-certified at least once up to 2016, including logging prior and during FSC certification, while least tree cover loss was found in non-certified areas, in contrast to losses in certified forests (Blumroeder et al. 2018).

The present study was carried out to test the postulated outcomes and underlying assumptions of a Theoretical Plausibility Analysis (Blumroeder et al. 2018), and to complement an Empirical Plausibility Analysis (Blumroeder et al. 2019), which was undertaken earlier to assess the ecological effectiveness of FSC certification in a case study located in the Arkhangelsk Region. For example, the FSC-Indicator 6.3.7 invites the hypothesis that clearcuts are smaller in size when harvesting is operated under FSC and reads as "The organization shall have a program to switch over from large-scale clearcuts to narrow clear-strip clearcuts and/ or small-size clearcuts (up to several hectares), shelterwood (multistage) cuts and/or selection cuts in forest types where it is feasible" (FSC 2012). Concretely, this 
study spatially assesses the impact of FSC certification by comparing tree cover loss and logging activities in certified areas with non-certified forest operations at two different spatial scales: (1) analyzing secondary impacts of clearcuttings on adjacent remnant forests and quantifying logging intensity in a sample area and (2) assessing the size and exhaustiveness of clearcuttings as well as the density of skidding trails within clearcuts.

\section{Methods}

The Arkhangelsk Region is located in the northwest of the Russian Federation and covered by a complex network of rivers and mires surrounded by an extensive forest area (Yaroshenko et al. 2001). The forest is of primary origin with large areas remaining intact and dominated by native spruce and pine species (Yaroshenko et al. 2001). Forestry is the main source of the economy in the region, and most of the activities are carried out in primary forests (Kobyakov and Jakovlev 2013; Angelstam et al. 2017). Timber harvesting is mainly conducted as clearcuts of up to 50 ha in compliance with the Russian forest legislation, also in primary forests, with severe negative ecological impacts (Blumroeder et al. 2018; Potapov et al. 2017; Potapov et al. 2009). In this study, clearcut is defined according to FSC as "harvesting in a designated area with retention of individual trees and shrubs (groups of trees and shrubs) to ensure forest regeneration" (FSC 2012).

In this study, information on the spatio-temporal distribution of FSC-certified forests in the Arkhangelsk Region as of May 2016 (FSC Russia and Transparent World 2016) was processed after revising issue dates of each certificate holder according to publicly available certificates (FSC 2016b). FSC-certificates are valid for a period of 5 years and terminated if renewal was not requested by the concession holder. Non-compliance with the standard requirements detected during annual surveillance audits can result in certificate suspension. In the Arkhangelsk Region, FSC-certification started in 2004 with two concession holders and proceeded to 41 certified concession holders in 2016. Due to termination or suspension of FSC-certificates, some logging companies were not certified permanently and constantly (Blumroeder et al. 2018).

In this analysis, we distinguished between areas with no history of certification (non-FSC in the following) and forests that had been managed before they became certified (before-FSC in the following) and subsequently under FSC (during-FSC in the following). Within a sample area delineating approximately $3000 \mathrm{~km}^{2}$ in the east of the Arkhangelsk Region, data generated by Hansen et al. (2013) on changes in global forest cover between 2001 and 2014 was used to calculate annual tree cover loss and the size of clearcuts in relation to the certification status. Previous studies showed that the sample area and clearcutting is typical for the region's forestry operations (Karvinen et al. 2006, 2011; Greenpeace International 2014, 2017; Blumroeder et al. 2018, 2019). Within the sample area, tree cover loss was classified manually from high-resolution (between $41 \mathrm{~cm}$ and $100 \mathrm{~cm}$ resolution) observation of Google Earth Pro satellite images (Google Earth Pro 2018) into five different categories according to their shape, structure, and size as follows: (1) clearcut logging (geometric quadrangle of cleared forest with visible signs of logging operations such as tree stumps and skidding trails), (2) forest fires (irregular burnt patches), (3) roads (straight lines), (4) diffuse small-scale canopy loss (covering less than $1 \mathrm{ha}$ ), and (5) undisturbed forest (no apparent canopy disturbance) (Fig. 1).

All logging activities within the sample area were conducted as clearcuts by three different concession holders. During the period of study, one company was never FSC-certified (non-FSC), while another two became certified and comprise clearcuts that were logged prior to certification (before-FSC) and while they were FSCcertified (during-FSC). The mean area logged was calculated as the annual mean area of clearcut in relation to the area covered by the concession and compared with the status of certification at the time of logging. Records of tree cover loss during the initial and final year of certification were excluded from the analysis to reduce uncertainty, as definite assignment to before-FSC or during-FSC seemed impossible. Furthermore, within the range of $1 \mathrm{~km}$ around each clearcut $(n=1096)$, the spatial distance to neighboring small-scale tree cover loss polygons that occurred in the subsequent years $(n=$ 4641) was determined. Spearman correlation coefficient was calculated to test the spatial interrelation between the clearcuts and the patches smaller than 1 ha.

In addition, a total of ten clearcuts which were also object of a previous study (compare a related study conducted on the same clearcuts Blumroeder et al. 2019) were scrutinized more specifically. The studied clearcuts were randomly selected within two neighboring logging concession holders who were cooperative in providing study plots but wished to remain anonymous. Clearcut harvesting was carried out between 2009 and 2011, while one company was applying FSC (certified since 2006 and thus cut during-FSC) and the other was operating without FSC (certified since 2013 and therefore logged before FSC was implemented). The edges of each clearcut, the alignment of skidding trails, and the configuration of forest remnants (defined as different types of forested patches within a clearcut, including the so-called seed trees, group of trees, key biotopes, and immature forests) were mapped and delineated using data on tree cover loss (Hansen et al. 2013), satellite images 


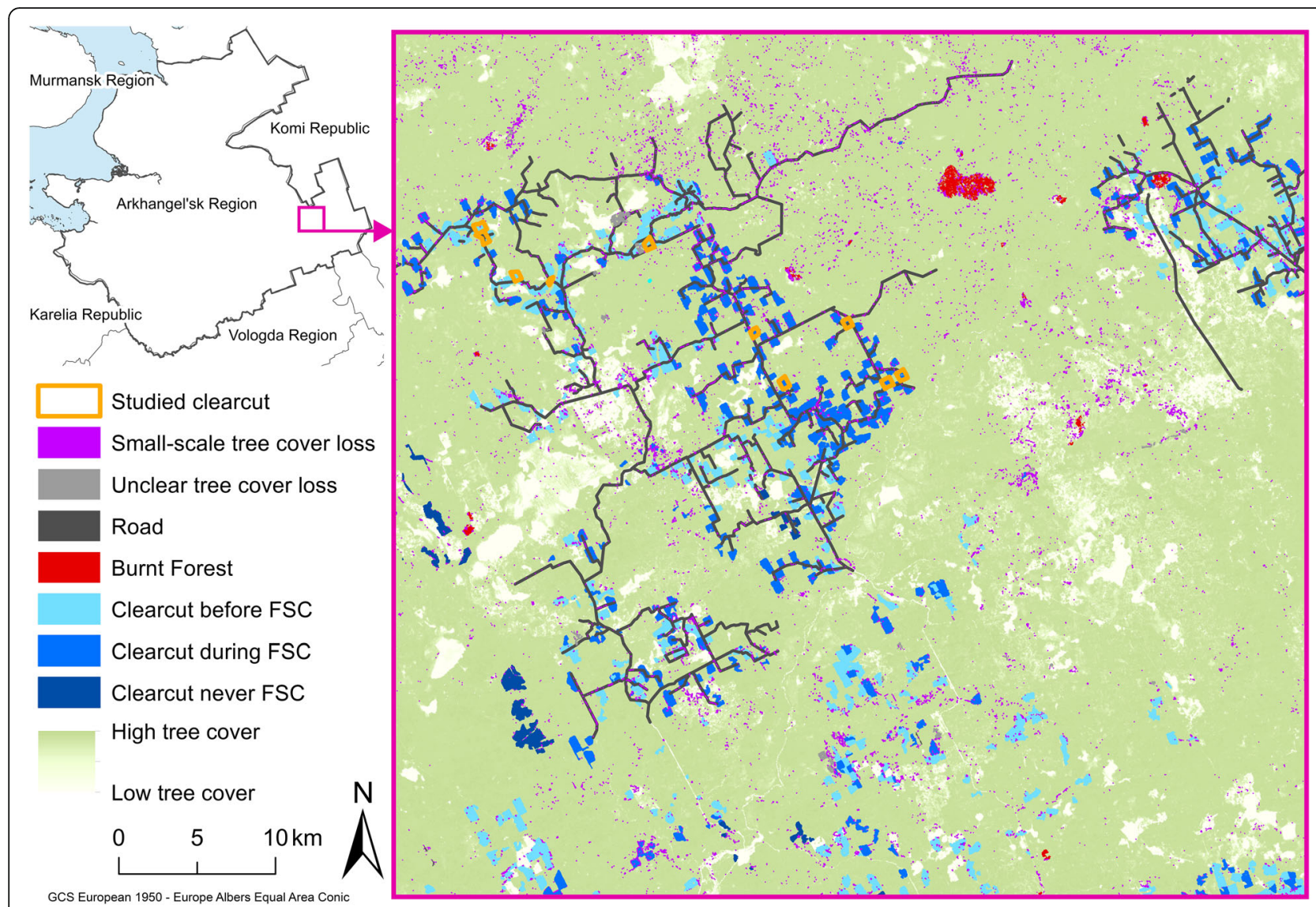

Fig. 1 Location of the sample area and investigated clearcuts in the east of the Arkhangelsk Region. Different colors represent different types of tree cover loss (Hansen et al. 2013) such as small-scale (below 1 ha), forest fires, and road as well as clearcut logging conducted before, during, and without FSC certification

(Google Earth Pro 2018), and obtainable forest management plans. Results for remote spatial analysis were subsequently followed-up with in-field verification in July 2017 using GPS tracking. To calculate the mean distance between skidding trails, a point matrix was created with points set at equidistance along the skidding trails. The distance between the skidding trails was calculated as mean distance between two points of neighboring trails.

All data processing and statistical analyses were performed in ArcGIS (ESRI 2011) and RStudio Version 1.1.456 (R Development Core Team 2018). Nonparametric statistical Kruskal-Wallis and subsequent Conover post hoc test were applied as alternative to ANOVA using the package PMCMR to test for differences between groups (Pohlert 2014).

\section{Results}

A comparison between FSC-certified and uncertified forest using data on the proportion of annually logged to untouched areas within the concessions revealed no significant difference $(p$ value $=0.30)($ Fig. 2).
Within the sample area, a significant, strong, and negative correlation between large-scale clearcuts and small-scale tree cover loss of less than 1 ha was detected, meaning that in the vicinity of large-scale patches of tree cover loss (including clearcuts), additional diffuse small-scale tree cover loss occurred $(r=-0.89 ; p$ value $<0.001)$ (Fig. 3). Equally, the extent of the area affected by small-scale tree cover loss was higher in areas closer to the larger tree cover loss polygons $(r=-0.9 ; p$ value $<0.001)$.

The spatial dimension of the ten randomly selected clearcuts was approximately 30 ha on average (before FSC: mean $=27.74$ ha, median $=32.83$ ha; during_FSC: mean $=30.12$; median $=32.20$ ha) without significant difference between clearcuts harvested before and during FSC-certification ( $p$ value $=0.46$ ). However, before-FSC clearings varied much more in size, also comprising the smallest clearcut of 7.6 ha (Fig. 4).

There was no evidence within the sampled area to indicate that the retention of forest remnants within the studied clearcuts increased in forests during-FSC ( $p$ value $=0.77$ ). In both certified and uncertified clearcuts, up to $97 \%$ of the area was completely cleared (Fig. 5). 


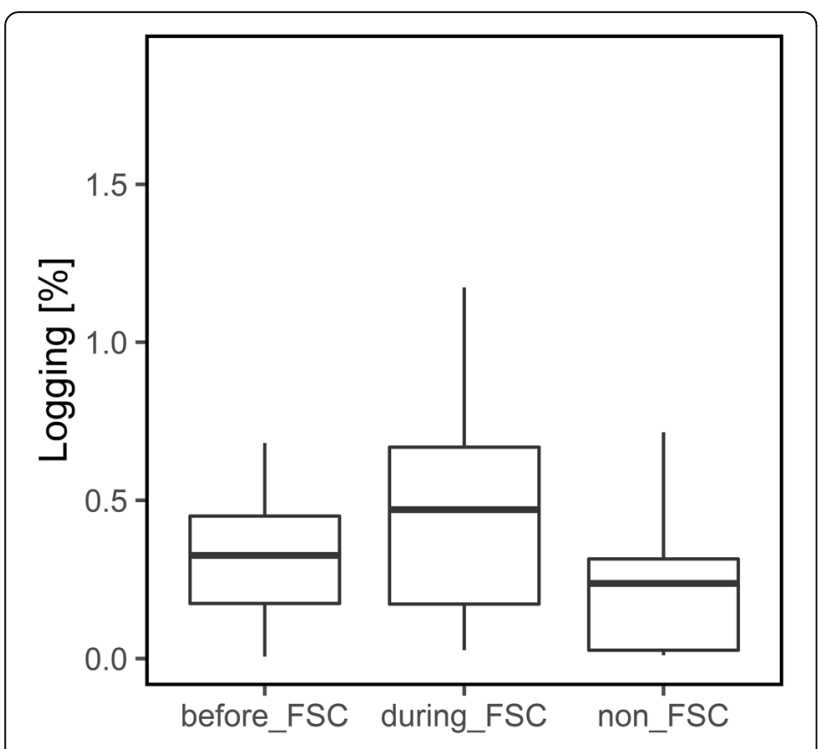

Fig. 2 Logging intensity in the sample area differentiating between areas that were under FSC-certification during the logging operation (during-FSC), areas that were harvested before they became certified (before-FSC), and areas that were never under certification (nonFSC): annual tree cover loss induced by logging in relation to the available area within the sampled study area

On two of the studied clearcuts that were cut during valid FSC-certification, $20 \%$ of tree cover was retained on logged sites covering immature forest with little economic value. In the case of one site that was logged before it was registered under FSC, more than $17 \%$ of the forest cover was spared from felling because of the presence of key biotopes and seed trees, while on other clearcuts, less than $7 \%$ of the initial tree cover was retained.

All skidding trails on the ten clearcuts were covered with felling residues as soil protection measure. The certification of forest under FSC made no significant difference to practices of harvesting and removal of trees and across the landscape skidding tracks were spaced on average less than $20 \mathrm{~m}$ apart $(p$ value $=0.5)($ Fig. 6).

\section{Discussion}

In this study, there was no evidence to indicate that FSC certification of forests leads to changes in harvesting practices in the studied clearcuts in the east of the Arkhangelsk Region. The extent of tree cover loss after the introduction of FSC remained equally high compared to as it was prior to certification or without certification within the sampled area. The results confirm the findings gained by Nikolaeva et al. (2019) showing that FSC certification did not induce changes in tree cover loss in the Russian Far East. The sixth FSC Principle, including FSC indicator 6.3.7, seems to be the most problematic in terms of non-compliance that was detected during audits (Lukashevich et al. 2016). The results are also in accordance with the findings of a previous study showing that FSC did not reduce annual tree cover loss (Blumroeder et al. 2018).

Our findings indicate that FSC failed to do the following:

(1) Reduce the size of clearcuts significantly;

(2) Increase the retention of seed trees on logged areas;

(3) Maintain larger tracts of undisturbed ground and soil on the investigated study sites and clearcuts represented by less skidding trails.

The practice of removing almost all economically profitable wood also contributes to further indirect effects of forest degradation and fragmentation, for example, an increase in edge effects as a result of opening the forest up to higher exposures of sunlight, wind, increased temperature variation, and other disturbances

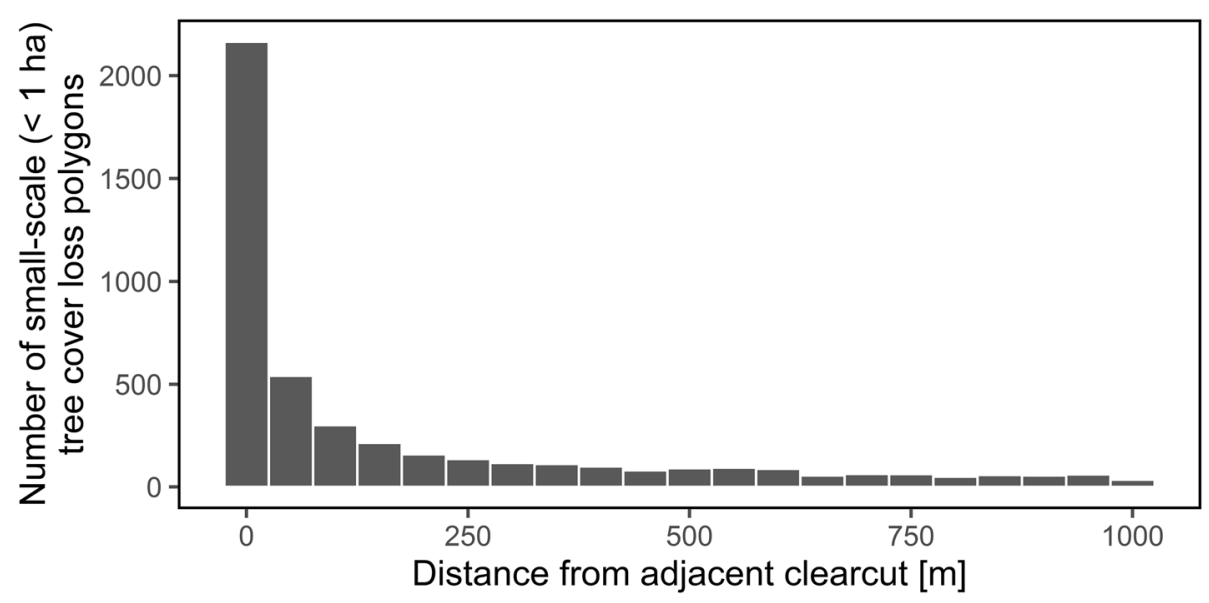

Fig. 3 Relationship between small- and large-scale tree cover loss in the sample area 


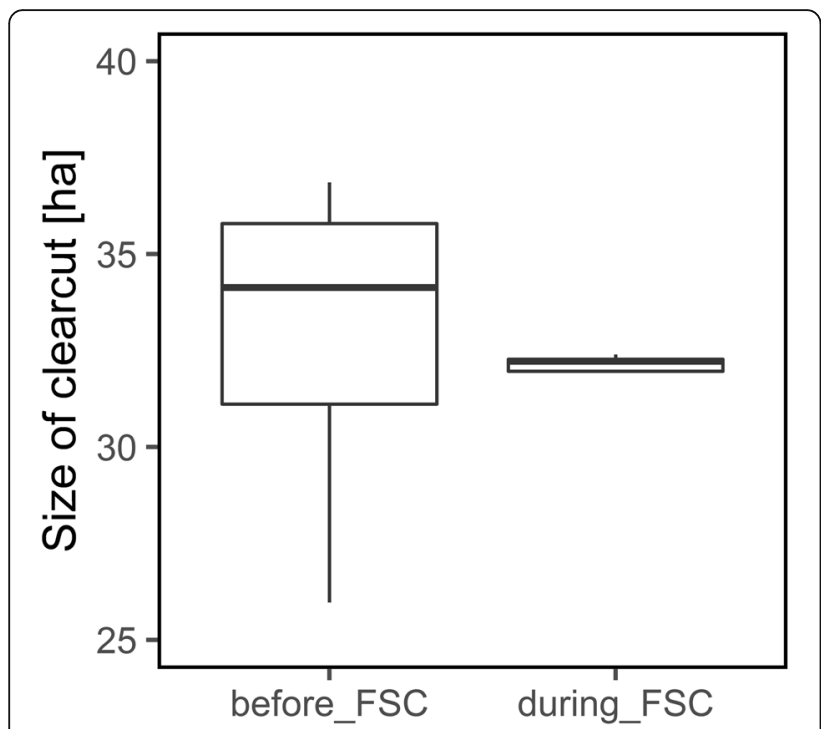

Fig. 4 Size of clearcuts before FSC certification $(n=5)$ and during valid FSC certification $(n=5)$

(Greenpeace International 2014; Schmiegelow and Mönkkönen 2002). Dramatic changes in forest patch dynamics towards larger, geometrical patterns may contribute to tree mortality and decreased food availability along the edges (Schmiegelow and Mönkkönen 2002).

The observed diffuse small-scale tree cover loss deserves special attention. In these remote inaccessible and uninhabited areas, it is unlikely that it is related to tree felling or direct anthropogenic interventions. Rather, it is plausible that it can be attributed to dieback of desiccated, flooded, infested, or windthrown trees. Apart from obvious natural dieback and gap formation, we observed

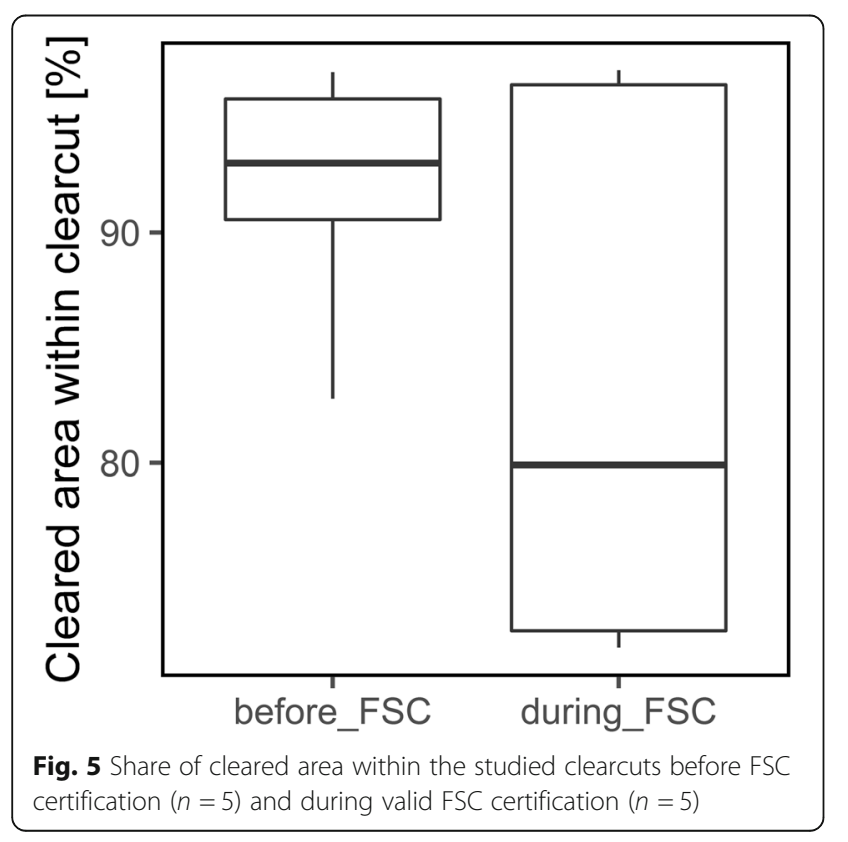

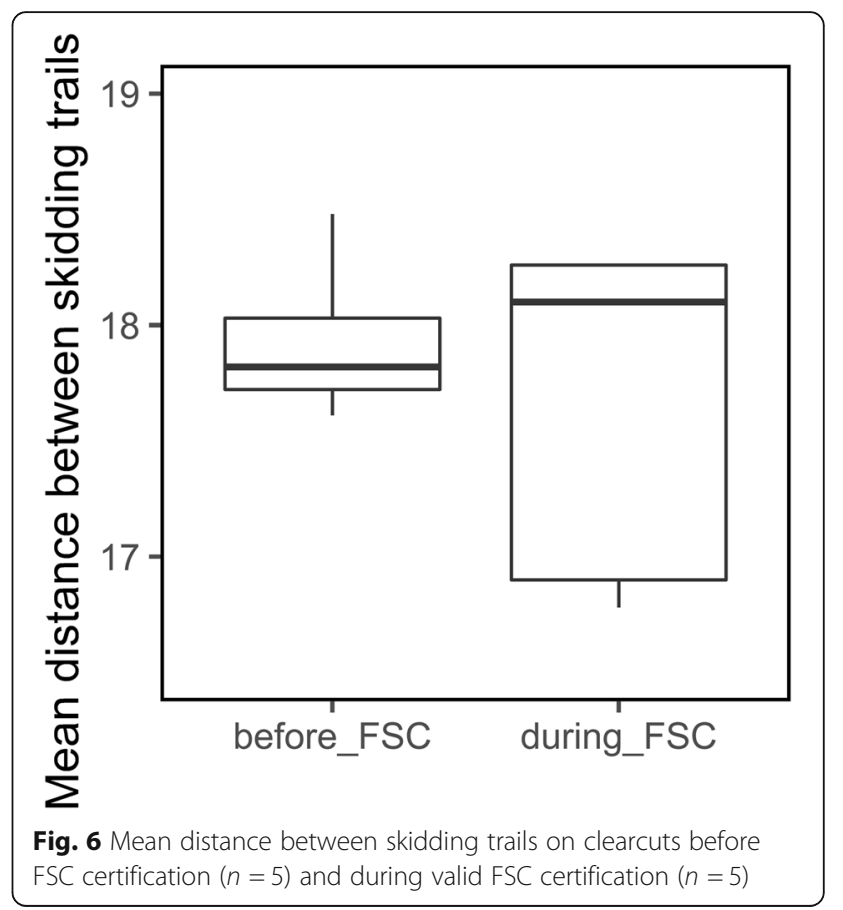

further small-scale dieback in forest adjacent to clearcuts, which had not been included in harvesting activities. As the findings indicate, within a $1-\mathrm{km}$ range around the clearcut range, a clear spatial relationship exists between diffuse dieback and larger clearcut areas. It is likely they represent secondary impacts of clearcuttings spreading into neighboring stands. There is evidence that edge effects can reach hundreds of meters inside the remaining forest ecosystem (Laurance 2000; Ries et al. 2004). Changes in both micro- and meso-climate, such as greater fluctuations in temperature and elevated maximum temperatures, possibly causing and interacting with hydrological changes, would increase vulnerability in trees already growing under extreme conditions (Blumroeder et al. 2019). Not only the direct loss of tree cover within cleared forest areas, but also the catalytic losses in remaining untouched forests due to fragmentation and increased forest edges is known to threaten the maintenance of forest functions and the stability of the ecosystem (Riitters et al. 2016). So far, these indirect effects caused by the anthropogenic manipulation of the boreal forest ecosystem are insufficiently understood and can represent an enormous risk that was masked for a long time, when cuttings were smaller and less frequent and when climate was more moderate. The large-scale clearcuts could have the potential of driving irreversible changes of the mesoclimate, thus increasing the vulnerability of both uncut and legally protected forests. The diffuse dieback in unused areas next to clearcuttings could increase their burnability and the corresponding risk of further indirect anthropogenic degradation. 
Clearcutting and concomitant mechanical disturbances by harvesting practices impact soils drastically, so much so, that scientists have classed these damaged soils as detritus turbozems (Dymov 2017). The combined effects of microclimatic and soil changes induced by the practice of large-scale and intensive "timber mining" can hamper natural forest succession and regeneration and create a long-term legacy of forest loss. In forest areas under FSC certification, the density of skidding trails within the studied clearcuts was not reduced. The initial ride on the forest floor has the most severe impact on the soil, especially on the topmost layer, while the wheel rut is impacted most (Tan et al. 2008; Cambi et al. 2015; Abdi et al. 2017). A combination of factors such as soil conditions and hydrology, as well as frequency and weight of mechanical disturbance, causes soil compaction that can take decades to recover (Cambi et al. 2015).

Tree retention can help to increase structural diversity of clearcuts to support biodiversity (Lindenmayer and Franklin 2003). Furthermore, increasing the level of retention enhances carbon storage (Santaniello et al. 2017). However, in our study, forest practices under FSC did appear to reduce the size range of forest clearings, but not the number of remaining trees or retained forest patches within the clearing. Larger volumes of remaining tree biomass would provide stronger support for biodiversity in terms of available habitats and regarding a reduction of severe threats to biota, but certain quantities of remaining biomass on clearcuts cannot substitute functions and services provided by primary forests (Gustafsson et al. 2010). The ecological effectiveness of voluntary set-asides is often poor, as mostly immature stands are spared from felling and because the structural and functional connectivity of forest ecosystems needed to maintain biodiversity are not considered (Elbakidze et al. 2016).

One of the main drivers for forestry companies in the Russian Northwest to engage with FSC is the increased access and sale to European markets (Rametsteiner and Simula 2003; Blackman and Rivera 2011; Romero et al. 2013; Henry and Tysiachniouk 2018). The attractions of lucrative markets in countries where there are strong public concerns for the environment encourages forestry companies to operate intensively under the umbrella of FSC. There is evidence to suggest FSC certification can even increase the rate and intensity of forest exploitation due to the high incentive for timber exports and sales market. This is also known from other biomes. For instance, in the Congo basin, tree cover loss in intact forest landscapes was higher in certified compared to non-certified concessions (Kleinschroth et al. 2019).

\section{Conclusions}

In order to induce quantifiable changes of the logging practices and safeguard ecosystem functionality, i.e., to increase the ecological effectiveness of FSC, current clearcutting practices would have to be replaced. The overexploitation of provisioning services, i.e., timber extraction, diminishes the ecosystems' capacity to maintain other services of global significance. It also reduces the ecosystem functionality important to cope with and adapt to other stresses and disturbances that are increasing under rapid climate change. In combination with earlier assessments (Blumroeder et al. 2018, 2019), this study confirms doubts that the Forest Stewardship Council is an appropriate mechanism for safeguarding ecologically responsible forest use in Russian forests. The Russian National FSC Standard fails to induce ecologically friendly cutting and harvesting methods in the studied area. As reaction to our earlier papers, FSC (Germany) accepted to a certain degree this critique (e.g., in Holz-Zentralblatt 30, 26 July 2019), but pointed out that an environmental benefit would be the protection of $19 \%$ of the certified forests in Russia. Still, it was impossible to obtain spatial data from FSC that would confirm that such a value also applies to the Arkhangelsk Region. Furthermore, it was impossible to verify if the mentioned protected areas covered only forests, or also included (unexploitable) non-forest areas such as mires, and if the legal protection was permanent and independent from the period of certification. Fundamental questions to be raised refer to the burden of proof as well as to FSC's transparency policy. But even if longterm set-aside of forests in the vicinities of the clearcuttings was confirmed, their effectiveness has to be assessed in the light of apparent edge effects and secondary dieback potentially triggered by large-scale clearcutting practices.

\section{Abbreviation \\ FSC: Forest Stewardship Council}

\section{Acknowledgements}

The authors thank the participating companies and their staff facilitating the research. Special thanks to the researchers from the NArFU - Northern (Arctic) Federal University in Arkhangelsk who supported the data collection on-site, especially Irina Amosova and Tatyana Parinova.

\section{Authors' contributions}

JSB led the methodological development, coordinated the fieldwork, conducted the data analyses and interpretation, wrote a first draft, and compiled the final manuscript. $\mathrm{MH}$ and $\mathrm{Ol}$ prepared and processed the spatial data. OI and SW conducted the data collection in the field. PH revised the manuscript. PLI, SW, and JSB co-conceived the study; PLI supervised it as senior author, especially participating in the methodological development, interpretation of the results, and writing. All authors read and approved the final manuscript.

\section{Funding}

The study was financed by the WWF Germany and the Eberswalde University for Sustainable Development. PLI conceived together with JSB and supervised the study in the framework of his long-term research program facilitated by the research professorships "Biodiversity and natural resource management under global change" (2009-2015) as well as "Ecosystem-based sustainable development" (since 2015) granted by Eberswalde University for Sustainable Development. 


\section{Availability of data and materials}

The datasets analyzed in the current study are available in the Hansen/UMD/ Google/USGS/NASA repository, Hansen, M.C., Potapov, P. V, Moore, R., Hancher, M., Turubanova, S. a, Tyukavina, A., Thau, D., Stehman, S. V, Goetz, S.J., Loveland, T.R., Kommareddy, A., Egorov, A., Chini, L., Justice, C.O., Townshend, J.R.G., 2013. High-resolution global maps of twenty-first century forest cover change. Science (80-.). 342, 850-853. doi:https://doi.org/10.1126/ science.1244693. https://earthenginepartners.appspot.com/science-2013-global-forest/download_v1.5.html and FSC Russia, Transparent World https://ru. fsc.org/download-box.1778.htm.

\section{Ethics approval and consent to participate}

Not applicable

\section{Consent for publication}

Not applicable

\section{Competing interests}

The authors declare that they have no competing interests.

\section{Author details}

'Centre for Econics and Ecosystem Management, Eberswalde University for Sustainable Development, Alfred-Moeller-Str. 1, 16225 Eberswalde, Germany. ${ }_{2}^{2}$ Petrozavodsk State University, Lenina st. 33, 185000 Petrozavodsk, Russia. ${ }^{3}$ Karelian Nature Conservancy (SPOK), Petrozavodsk, Russia. ${ }^{4}$ WWF Germany, Reinhardtstr, 18, 10117 Berlin, Germany. ${ }^{5}$ Centre for Econics and Ecosystem Management, Writtle University College, Lordship Road, Writtle Chelmsford Essex CM1 3RR, UK.

Received: 9 November 2019 Accepted: 15 January 2020

Published online: 14 February 2020

\section{References}

Abdi E, Moghadamirad M, Hayati E, Jaeger D (2017) Soil hydrophysical degradation associated with forest operations. Forest Sci Technol 13:152-157. https://doi.org/10.1080/21580103.2017.1387611

Achard F, Mollicone D, Stibig H-J et al (2006) Areas of rapid forest-cover change in boreal Eurasia. For Ecol Manag 237:322-334. https://doi.org/10.1016/j. foreco.2006.09.080

Angelstam P, Naumov V, Elbakidze M (2017) Transitioning from Soviet wood mining to sustainable forest management by intensification: are tree growth rates different in northwest Russia and Sweden? Forestry 90:292-303. https:// doi.org/10.1093/forestry/cpw055

Auld G, Gulbrandsen LH, McDermott CL (2008) Certification schemes and the impacts on forests and forestry. Annu Rev Environ Resour 33:187-211. https://doi.org/10.1146/annurev.environ.33.013007.103754

Blackman A, Goff L, Planter MR (2015) Does eco-certification stem tropical deforestation? Forest Stewardship Council certification in Mexico

Blackman A, Rivera J (2010) The evidence base for environmental and socioeconomic impacts of sustainable certification. Resources for the Future, Washington, DC

Blackman A, Rivera J (2011) Producer-level benefits of sustainability certification. Conserv Biol 25:1176-1185. https://doi.org/10.1111/j.1523-1739.2011.01774.X

Blumroeder JS, Burova N, Winter S et al (2019) Ecological effects of clearcutting practices in a boreal forest (Arkhangelsk Region, Russian Federation) both with and without FSC certification. Ecol Indic 106. https://doi.org/10.1016/j. ecolind.2019.105461

Blumroeder JS, Hobson PR, Graebener UF et al (2018) Towards the evaluation of the ecological effectiveness of the principles, criteria and indicators $(\mathrm{PCl})$ of the Forest Stewardship Council (FSC): case study in the Arkhangelsk Region in the Russian Federation. Challenges Sustain 6:20-51. https://doi.org/10. 12924/cis2018.06010020

Bradshaw CJA, Warkentin IG, Sodhi NS (2009) Urgent preservation of boreal carbon stocks and biodiversity. Trends Ecol Evol 24:541-548. https://doi.org/ 10.1016/j.tree.2009.03.019

Burivalova Z, Hua F, Koh LP et al (2017) A critical comparison of conventional, certified, and community management of tropical forests for timber in terms of environmental, economic, and social variables. Conserv Lett 10:4-14. https://doi.org/10.1111/conl.12244
Cambi M, Certini G, Neri F, Marchi E (2015) The impact of heavy traffic on forest soils: a review. For Ecol Manag 338:124-138. https://doi.org/10.1016/j.foreco. 2014.11.022

Dymov AA (2017) The impact of clearcutting in boreal forests of Russia on soils: a review. Eurasian Soil Sci 50:780-790. https://doi.org/10.1134/ S106422931707002X

Elbakidze M, Ražauskaite R, Manton M et al (2016) The role of forest certification for biodiversity conservation: Lithuania as a case study. Eur J For Res 135: 361-376. https://doi.org/10.1007/s10342-016-0940-4

ESRI (2011) ArCMAP 10.2

FSC (2012) FSC Forest Stewardship Council Standard for Russian Federation: FSC-STDRUS-V6-1-2012 Russia Natural and Plantations EN. Russian Federation, Moscow

Forest Stewardship Council Russia, Transparent World (2016) FSC-сертифицированные леса в Европейской России: выданные сертификаты. https://ru.fsc.org/preview. fsc.a-1780.jpg. Accessed 1 Jul 2017.

FSC (2016a) FSC: a tool to implement the sustainable development goals. Mexico FSC (2016b) Public Certificate Search Forest Stewardship Council F000100, FSC. https://info.fsc.org/certificate.php. Accessed 10 May 2017

FSC (2019) Facts \& Figures. In: Sept. 6, 2019. https://fsc.org/en/page/facts-figures

Gauthier S, Bernier P, Kuuluvainen T et al (2015) Boreal forest health and global change. Science 349:819-822. https://doi.org/10.1126/science.aaa9092

Google Earth Pro (2018) (7.3.2.5776). Arkhangelsk, Russian Federation. Image Landsat/Copernicus. Image @ 2018 Maxar Technologies @ 2018 Google [April 27, 2018]

Greenpeace International (2014) FSC at Risk. FSC in Russia: Certifying the destruction of intact forest landscapes. Greenpeace International, Amsterdam

Greenpeace International (2017) EYE ON THE TAIGA: How Industry's claimed "sustainable forestry" in Russia is destroying the great Northern Forest. Greenpeace International, Amsterdam

Gulbrandsen LH (2005) The effectiveness of non-state governance schemes: a comparative study of forest certification in Norway and Sweden. Int Environ Agreements 5:125-149. https://doi.org/10.1007/s10784-004-1010-9

Gustafsson L, Kouki J, Sverdrup-Thygeson A (2010) Tree retention as a conservation measure in clear-cut forests of northern Europe: a review of ecological consequences. Scand J For Res 25:295-308. https://doi.org/10. 1080/02827581.2010.497495

Hansen MC, Potapov PV, Moore R et al (2013) High-resolution global maps of 21 st-century forest cover change. Science 342:850-853. https://doi.org/10. 1126/science. 1244693

Hanski I, Ovaskainen O (2000) The metapopulation capacity of a fragmented landscape. Nature 404:755-758. https://doi.org/10.1038/35008063

Hanski IK, Haila Y (1988) Singing territories and home ranges of breeding Chaffinches: visual observation vs. radio-tracking. Ornis Fenn 65:97-103

Henry LA, Tysiachniouk M (2018) The uneven response to global environmental governance: Russia's contentious politics of forest certification. For Policy Econ 90:97-105. https://doi.org/10.1016/j.forpol.2018.01.014

Hewson J, Crema SC, Gonzáles-Roglich M et al (2019) New 1 km resolution datasets of global and regional risks of tree cover loss. Land 8:1-14. https:// doi.org/10.3390/land8010014

Holden SR, Treseder KK (2013) A meta-analysis of soil microbial biomass responses to forest disturbances. Front Microbiol 4:1-17. https://doi.org/10. 3389/fmicb.2013.00163

Karvinen S, Välkky E, Gerasimov Y, Dobrovolsky A (2011) Northwest Russian Forest Sector in a Nutshell. Finnish Forest Research Institute, Sastamala

Karvinen S, Välkky E, Torniainen T, Gerasimov Y (2006) Northwest Russian Forestry in a Nutshell. Working Papers of the Finnish Forest Research Institute, Helsinki

Kleinschroth F, Garcia C, Ghazoul J (2019) Reconciling certification and intact forest landscape conservation. Ambio 48:153-159. https://doi.org/10.1007/ s13280-018-1063-6

Kobyakov K, Jakovlev J (eds.) (2013) Atlas of high conservation value areas, and analysis of gaps and representativeness of the protected area network in northwest Russia: Arkhangelsk, Vologda, Leningrad, and Murmansk Regions, Republic of Karelia, and City of St. Petersburg. Finnish Environment Institute. Helsinki. 517 p

Laurance WF (2000) Do edge effects occur over large spatial scales? Trends Ecol Evol 15:134-135

Lindenmayer DB, Franklin JF (2003) Towards forest sustainability. CSIRO Publishing, Collingwood, 231

Lukashevich V, Shegelman I, Vasilyev A, Lukashevich M (2016) Forest certification in Russia: development, current state and problems, vol 62, pp 48-55. https://doi.org/10.1515/forj-2016-0006 
Marx A, Cuypers D (2010) Forest certification as a global environmental governance tool: what is the macro-effectiveness of the Forest Stewardship Council? Regul Gov 4:408-434. https://doi.org/10.1111/j.1748-5991.2010.01088.x

McDermott CL, Cashore B, Kanowski P (2010) Central and Eastern Europe: Latvia, Poland and the Russian Federation. In: Global environmental Forest policies: an international comparison. Earthscan, London; Washington, DC

Miura S, Amacher M, Hofer T et al (2015) Protective functions and ecosystem services of global forests in the past quarter-century. For Ecol Manag 352:3546. https://doi.org/10.1016/j.foreco.2015.03.039

Naumov V, Angelstam P (2014) Intensifying Forestry in NW Russia?: The Roles of Landscape History and Tree Growth. School for Forest Management, Swedish University of Agricultural Sciences.

Nawaz MF, Bourrié G, Trolard F (2012) Soil compaction impact and modelling. A review. Agron Sustain Dev 33:291-309. https://doi.org/10.1007/s13593-011-0071-8

Nikolaeva AS, Kelly M, O'Hara KL (2019) Differences in forest management practices in Primorsky Krai: case study of certified and non-certified by Forest Stewardship Council Forest Concessions. J Sustain For 1-15. https://doi.org/ 10.1080/10549811.2019.1573147

Pohlert T (2014) The pairwise multiple comparison of mean ranks package (PMCMR). R package

Potapov P, Hansen MC, Laestadius L et al (2017) The last frontiers of wilderness: tracking loss of intact forest landscapes from 2000 to 2013. Sci Adv 3:1-13. https://doi.org/10.1126/sciadv.1600821

Potapov P, Laestadius L, Yaroshenko A, Turubanova S (2009) Global mapping and monitoring the extent of forest alteration: the intact forest landscapes method. FAO, Forest resources assessment, working paper 166, Rome

Potapov P, Yaroshenko A, Turubanova S et al (2008) Mapping the world's intact forest landscapes by remote sensing. Ecol Soc 13:51

R Development Core Team (2018) R: a language and environment for statistical computing. R version 3.5.1 (2018-07-02) R Foundation for Statistical Computing, Vienna. https://www.R-project.org/

Rametsteiner E, Simula M (2003) Forest certification —an instrument to promote sustainable forest management? J Environ Manag 67:87-98. https://doi.org/ 10.1016/S0301-4797(02)00191-3

Ries L, Fletcher RJ, Battin J, Sisk TD (2004) Ecological responses to habitat edges: mechanisms, models, and variability explained. Annu Rev Ecol Evol Syst 35: 491-522. https://doi.org/10.1146/annurev.ecolsys.35.112202.130148

Riitters K, Wickham J, Costanza JK, Vogt P (2016) A global evaluation of forest interior area dynamics using tree cover data from 2000 to 2012. Landsc Ecol 31:137-148. https://doi.org/10.1007/s10980-015-0270-9

Romero C, Putz FE, Guariguata MR, et al (2013) An overview of current knowledge about the impacts of forest management certification: a proposed framework for its evaluation. Occasional paper 91 CIFOR, Bogor

Santaniello F, Djupström LB, Ranius T et al (2017) Simulated long-term effects of varying tree retention on wood production, dead wood and carbon stock changes. J Environ Manag 201:37-44. https:/doi.org/10.1016/j.jenvman.2017.06.026

Schmiegelow FKA, Mönkkönen M (2002) Habitat loss and fragmentation in dynamic landscape: avian perspectives from the boreal forest. Ecol Appl 12: 375-389. https://doi.org/10.1890/1051-0761(2002)012[0375:HLAFID]2.0.CO;2

Startsev AD, McNabb DH (2009) Effects of compaction on aeration and morphology of boreal forest soils in Alberta, Canada. Can J Soil Sci 89:45-56

Tan X, Chang SX, Kabzems R (2005) Effects of soil compaction and forest floor removal on soil microbial properties and $\mathrm{N}$ transformations in a boreal forest long-term soil productivity study. For Ecol Manag 217:158-170. https://doi. org/10.1016/j.foreco.2005.05.061

Tan X, Chang SX, Kabzems R (2008) Soil compaction and forest floor removal reduced microbial biomass and enzyme activities in a boreal aspen forest soil. Biol Fertil Soils 44:471-479. https://doi.org/10.1007/s00374-007-0229-3

Thompson ID, Okabe K, Tylianakis JM et al (2011) Forest biodiversity and the delivery of ecosystem goods and services: translating science into policy. Bioscience 61:972-981. https://doi.org/10.1525/bio.2011.61.12.7

Ugarte S, D'Hollander D, Tregurtha N, Haase N (2017) SDGs mean business: how can credible standards help companies deliver the 2030 agenda. WWF, Switzerland

Watson JEM, Dudley N, Segan DB, Hockings M (2014) The performance and potential of protected areas. Nature 515:67-73

Yaroshenko AY, Potapov PV, Turubanova SA (2001) The last intact forest landscapes of northern European Russia. Greenpeace Russia, Moscow

\section{Publisher's Note}

Springer Nature remains neutral with regard to jurisdictional claims in published maps and institutional affiliations.

\section{Submit your manuscript to a SpringerOpen ${ }^{\circ}$ journal and benefit from:}

- Convenient online submission

- Rigorous peer review

- Open access: articles freely available online

- High visibility within the field

- Retaining the copyright to your article

Submit your next manuscript at $\boldsymbol{\nabla}$ springeropen.com 